\title{
EFFECTING CHANGE \\ IN LIMITED-CONTROL \\ CLASSROOM ENVIRONMENTS
}

\author{
A CASE STUDY
}

Allison P. Boye, Texas Tech University

Many instructors face the dilemma of possessing little control over their own curriculum or even their own pedagogy. This chapter examines three instructors who were teaching the same course over several years, facing the same problematic issues beyond their control, and describes the role of faculty developers in belping effect practical change for those instructors and for the course. The findings of this study, using longitudinal data derived from student evaluations and qualitative responses from instructor interviews, suggest that faculty developers can help instructors realize change on an individual level as well as at the department and big-picture levels.

Louise, Alex, and Ashley all had problems teaching. Their students thought the course material was too difficult and often boring, and they frequently came to class with bad attitudes. Yet despite their desire to improve, these instructors felt disempowered to make any changes. For three years, faculty developer colleagues at my center and I worked with these three graduate student instructors (GSIs) who were teaching the same course: a large, required course in food sanitation. Each year we helped these instructors, who were also participants in our graduate student development program, try to navigate the pedagogical challenges of

I thank Suzanne Tapp for her invaluable insights and support during the completion of this project, as well as the instructors and faculty members who were involved, for allowing me to share their experiences. 
the course, and we noticed that the same problems appeared each year. Unfortunately, most of the course's ongoing problems had less to do with the individual GSIs than with curricular and departmental issues that were out of their control.

Any faculty developers who have worked with GSIs or new or adjunct faculty have likely encountered instructors who are teaching something they have been told to teach, with little or no control over content, pedagogical, or logistical decisions. Those instructors might feel pressured to conform to a certain style of teaching that may or may not match their own preferences, or perhaps they are teaching content with which they are unfamiliar and must rely on another's material just to get by. This circumstance is certainly not unusual, but it surely changes the way a faculty developer is able to interact with and advise instructors who are seeking improvements in the classroom. This conundrum begs the question: If the instructor does not have the authority to make the changes that are really necessary for the most improvement, what can a faculty developer do?

\section{The Perfect Storm: A Case Study}

This case study focuses on GSIs, identified here as Louise, Alex, and Ashley, who taught the same course in food sanitation in the department of animal and food sciences over three different years (2006-2007, 2008-2009, 2009-2010). During each of those academic years, respectively, the GSIs were participants in a graduate student development program, the Teaching Effectiveness And Career enHancement Program (TEACH), at Texas Tech University, and they worked closely with faculty developers while teaching the course. As part of $\mathrm{TEACH}$, each semester faculty developers observed the instructors in the classroom, provided feedback, and conducted a small group instructional diagnosis (SGID), a well-known form of midterm student evaluation in which individual as well as group consensus feedback is solicited (Clark \& Redmond, 1982). As we worked with these GSIs, we noticed ourselves making many of the same suggestions, and students making many of the same complaints, year after year.

\section{A Brief Overview of the Literature}

Although little has been written about the lack of curricular or pedagogical control full-time faculty might face, GSIs and adjuncts are undoubtedly the most likely to lack control over their own teaching environment. 
Literature confirms that adjunct instructors, often fearful of losing their positions, also suffer from limited academic freedom (Marshall, 2003; Schneider, 1999; Thompson, 2003). Much of the literature about GSIs confirms that they, like adjuncts, do not receive a great deal of training or support for their teaching (Association of American Universities, 1998; Gaff, 2002a, 2002b; Golde \& Dore, 2001; Kuther, 2003; Meacham, 2002; Park, 2002; Weisbuch, 2004). Meacham (2002) in particular claims that lack of pedagogical preparation is a failure by universities not only for the graduate students, but also for the undergraduate students in their care. In a survey of perceptions of using GSIs, Park (2002) explores both the benefits and drawbacks. The notable drawbacks include confusion that may be created if the GSI teaches differently from the course leader, as well as tension fostered by the lack of ownership in the teaching process. Both concerns are related to the issue of control that the instructors in this case study experienced. In addition, Prieto and Meyers (1999) highlight the increase in self-efficacy or confidence that GSIs who receive support and training realized.

The literature also substantiates that resistance to faculty development and the difficulty of pedagogical change, such as that experienced by the instructors in this study, are not new. Common reasons for such resistance include concerns about not having the time to implement change, that help or change is unnecessary, or that the need for faculty development implies incompetence on the part of the instructor (Boice, 1984; Turner \& Boice, 1986). Hodges (2006) notes that fear of risk taking can play a large part in impeding change and emphasizes the importance of small changes that do not remove instructors far from their comfort zones, while Hativa (2000) focuses on the significance of addressing personal beliefs about teaching with instructors. All of these issues are likely familiar to experienced faculty developers, and indeed they were taken into consideration when working with the instructors in this study.

One major concern in this case study was the faculty developer's ability to act as an agent of change, even in the face of such resistance. Several authors call for faculty developers to take a decidedly proactive approach toward becoming change agents on their campuses (Cook, 2001; Diamond, 2005; Fletcher \& Patrick, 1998; Zahorski, 1993). Gardiner (2005) specifically asserts the importance of developing a sense of urgency for change. Cook (2001) further corroborates that faculty developers can be helpful partners in curricular change, given their position as objective observers and their ability to provide empirical evidence of the need for change. Finally, others (Boye \& Meixner, 2010; Brookfield, 1995; Loughran, 2002; McAlpine \& Weston, 2000) underscore the value 
of instructor reflection in the transformation and development process, something that we also demonstrated in this study.

\section{What Students Had to Say}

To determine if what appeared to be recurring problems with the food sanitation course truly were just that, content analysis was conducted of the individual comments from all six semesters of SGID data for the three graduate instructors. That analysis confirmed that each year, nine common themes continued to surface from student feedback, in almost exact proportions; each year, approximately 33 to 37 percent of the total student feedback related to nine common complaints (Table 7.1):

1. Amount of material

2. Difficulty of material or grading

3. Pace too fast

Table 7.1 Major Common Themes in Individual Student SGID Comments

\begin{tabular}{|c|c|c|c|}
\hline Common Theme & $\begin{array}{l}\text { Common Theme } \\
\text { Comments, } \\
\text { 2006-2007 }\end{array}$ & $\begin{array}{l}\text { Common Theme } \\
\text { Comments, } \\
\text { 2008-2009 }\end{array}$ & $\begin{array}{l}\text { Common Them } \\
\text { Comments, } \\
\text { 2009-2010 }\end{array}$ \\
\hline Amount of material & $17.5 \%$ & $10.0 \%$ & $15.6 \%$ \\
\hline $\begin{array}{l}\text { Difficulty of material } \\
\text { or grading }\end{array}$ & 15.7 & 23.8 & 25.4 \\
\hline Pace too fast & 27.9 & 17.9 & 12.3 \\
\hline $\begin{array}{l}\text { Desire for more } \\
\text { interaction }\end{array}$ & 24.9 & 32.2 & 31.4 \\
\hline $\begin{array}{l}\text { Too much lecture or } \\
\text { PowerPoint }\end{array}$ & 5.7 & 3.8 & 12.8 \\
\hline $\begin{array}{l}\text { Imbalance of majors } \\
\text { and nonmajors }\end{array}$ & 1.7 & 6.3 & .82 \\
\hline $\begin{array}{l}\text { Memorization } \\
\text { versus application of } \\
\text { material }\end{array}$ & 2.2 & 1.7 & 0 \\
\hline Location of class & 1.7 & 3.8 & .27 \\
\hline Team teaching & 2.6 & NA & 1.4 \\
\hline $\begin{array}{l}\text { Percentage of total } \\
\text { SGID comments } \\
\text { related to common } \\
\text { themes }\end{array}$ & 33.5 & 32.7 & 37.2 \\
\hline
\end{tabular}




\section{Desire for more interaction}

5. Too much lecture or PowerPoint

6. Imbalance of majors and nonmajors

7. Memorization versus application of material

8. Location of classes

9. Team teaching

Many of those common themes were related to issues outside the realm of control of the GSIs, for this course carried with it a host of unusual complicating factors. First, this course suffers from unbalanced demographics: although it is taught within the department of animal and food sciences, the instructors note that approximately 80 to 90 percent of the students come from the college of human sciences who are taking the course as required preparation for the national ServSafe exam before entering the restaurant and hospitality industries. Second, the animal and food sciences building is for all intents and purposes off-campus, a mile and a half away from the human sciences building. Walking between the two buildings takes about twenty minutes; taking the campus bus takes approximately seventeen minutes due to the five stops in between; either option takes far longer than the ten minutes allotted between classes. Therefore, the instructors typically start class late and finish early to accommodate students from human sciences. The class consists of 100 to 130 students each semester, and the classroom has fixed stadium seating with long tables and entrances at the front. The professor who coordinates the course and team-teaches with the graduate students is well established and respected, and in general, her lecture style dominates.

The yearly complaints from students about amount of material, difficulty of material, and application of material all clearly relate to the palpable divide between majors and nonmajors in the course. Many students, particularly human sciences students, did not understand the relevance of the vast amounts of material in the class, since it was their understanding that the course was meant solely as preparation for the ServSafe exam. One student wrote, "The endless barrage of microbiology terms is completely useless because it retains no context due to the vast majority of sanitation issues being solved with simple rules which can be retained in any on-the-job sanitation course." However, both the professor and graduate instructors verified that additional material was geared toward the more advanced animal and food science majors. Similarly, human sciences students repeatedly cried out for more direct application of the material to their own future careers, writing statements such as, 
"I'd like to learn more about food procedures and things I will actually use in a kitchen/restaurant, NOT MEMORIZING things I will forget in 2 weeks." Some comments, which could not be separated into distinct pedagogical categories, but only as majors versus nonmajors, likewise gave strong voice to the tangible divide between animal and food science majors and human sciences majors each year, such as, "When taking this class [human sciences] majors and [animal and food science] majors should not have to take this class together. It should be separate."

The complaints about the rapid pace of the course are also somewhat related to the location of the classroom. The need to cover the vast amount of material in a relatively short time becomes even more complicated when each class period is shortened by ten to twenty minutes to allow travel across campus. Each semester, students would make comments such as, "I understand there is a lot of material to be covered, but the rushed feeling throughout lectures really just stresses me out and affects my ability to really learn the material." Students already struggling with difficult, unfamiliar material thus struggled even further with the brisk pace of instruction.

The concerns over excessive PowerPoint-driven lecture and a desire for more class interaction had much to do with not only the restrictive physical space of the classroom itself (perceived as unfavorable for learning activities that require movement or interaction), but also with fear experienced by some of the GSIs about straying too far from the traditional style of the course. One of the graduate instructors, for instance, revealed that she "felt it was best to mimic the instructor of record's style to maintain consistency," even though she wanted to try other activities and styles of teaching. While the students appreciated the structure and clarity provided by the use of PowerPoint, they did not like the monotony of feverishly scribbling notes and listening to lecture every class or, as one student wrote, "Slide after slide after slide after slide." Each year they also made comments asking for more variety and interaction in the class, such as, "I am a hands-on learner, so I would like to see more of that instead of constant lecture." Students in the course obviously shared many similar concerns, and interestingly, the GSIs did as well.

\section{What GSIs Had to Say}

To gain further insight into the course from the instructors' perspectives, feedback was also gathered during interviews with the three former GSIs by e-mail, before which they granted permission for use of their comments and information related to the course for this project. 
Each instructor expressed similar frustrations with the tension created by the unbalanced demographics of the course. Each also echoed student concerns about the amount of material and the need to separate majors and nonmajors, making comments such as, "I would have reduced the amount of material or split the course into two separate sessions, with one being for science-based students, and the other being for the nonmajors. By doing this, I could adjust the type of material that was covered in the course and the way that the material was being presented to the students."

Further resonating with the tensions observed in Park's study (2002), one of the instructors stressed her unfulfilled desire to try out new teaching styles and vary the methods traditionally used in the course, especially in relation to the varying needs of the two groups of students. She remarked, "It was difficult not being able to change the style of teaching and method of presenting material to accommodate the students in the class. Facing a large group of uninterested and grumpy students each class period was difficult." The other GSIs confirmed the generally low morale or poor attitudes of disgruntled students in the class. Undoubtedly these graduate instructors were in tune with course issues that were creating unhappy students and had their own ideas about how to solve some of those problems; unfortunately, they felt they had no authority to do so.

\section{What the Faculty Developer Can Do: Multiple Levels of Change}

The food sanitation course is a perfect storm of sorts. Most courses, we hope, are not quite as complicated. Nevertheless, this case study focuses on the ultimate concern of what faculty developers can do to help instructors, like Louise, Alex, and Ashley, who have little control over their own curriculum and even pedagogy. The experiences of these instructors suggest that faculty developers can help such instructors realize multiple levels of change and growth.

\section{Instructor-Level Change}

The first level of change resides with the individual instructor. While the major changes needed might seem impossible, faculty developers must remember that there are elements within the instructor's control. While working with Louise, Alex, and Ashley, we helped them focus on what they could control and change at the moment and distinguish that from what they could not control. For instance, in our written feedback 
and discussion of our observations and the SGID, we purposely-even visually-separated the commentary that pertained specifically to the instructor from that which pertained to the uncontrollable course situation, and focused on the former. We maintained confidentiality and let the instructors determine if they wanted to share the feedback with their course advisor, hoping that if they did so, others in the department would have an opportunity to hear student feedback.

We furthermore assisted the instructors with tangible, immediate changes, such as how they designed and animated PowerPoint slides, since that was the major vehicle of instruction for all of them. We helped one instructor think through her classroom management style as she tried new strategies for handling the sometimes unruly, discontented students. And for another, we visited her classroom to provide feedback for her first attempt at a new small group activity.

While these interventions might seem inconsequential in light of the larger frustrations of the course, the instructors indicated that their impact was significant. One noted, for instance, that the faculty developers "gave [her] great ideas to use for getting a big group of students to participate" and that they were "very influential in the changes to [her] overall teaching approach.” And just as Prieto and Meyers's study (1999) might have predicted, faculty developer support played an important role in improved self-efficacy, for another commented, "The TEACH staff gave me more confidence in my teaching style and methods. ... The staff gave me many suggestions on how to handle the difficult students and how to be strong when faced with difficult situations." As such, we as faculty developers were able to meet some of the personal and pressing needs of individual instructors seeking instructional improvement.

\section{Department-and Program-Level Change}

As faculty developers, we are perhaps most comfortable working directly with individual instructors. Similarly, those instructors are likely used to dealing with their own departments regarding curriculum and program design, especially with respect to elements they may not feel they can change. What might be less common is the faculty developer working directly with the department to effect change when appropriate. Faculty developers have been urged to become more purposeful change agents (Cook, 2001; Diamond, 2005; Fletcher \& Patrick, 1998; Zahorski, 1993), and this study demonstrated the positive effect of answering that call. 
Given the large amount of consistent student feedback data available on the food sanitation course and the length of time our center had worked with course instructors, I decided the time was right to bring together the faculty with the most authority regarding the course: the course advisor from the department of animal and food sciences, who is in charge of designing the course, and the chair of the restaurant and hospitality industry management department, whose students make up the majority of the class. The goal was to present an overview of the data and facilitate a discussion about the status of the course.

I maintained a neutral position as the faculty developer while engaging with these faculty members. I did not call the meeting with the purpose of dictating what I thought should be done with the course; instead, I simply presented the data and said, "Here is what I have gathered about this course, and I thought you might find it interesting and want to talk about it together." That neutrality was crucial in preventing those department heads, who had not willingly solicited this interaction or feedback, from feeling ambushed or attacked; the goal was to help them maintain a feeling of control and an open mind, for I believe that only with openness can change be accomplished. I also maintained instructor confidentiality: I shared only the general overview of the SGID data and a few representative comments related to the common feedback themes.

Although I was unsure of how these department heads might respond to this unsolicited feedback, the meeting was ultimately a resounding success. The chairs spent only a few minutes skimming the data, confirming that they were both at least somewhat aware of the course's issues. They then immediately turned to me and asked for suggestions for change. In response, I returned to the data and what I had learned from the instructor interviews for support and made suggestions centered on the two major complaints: creating two sections of the course-one for majors and one for nonmajors-so that the material can be more tailored to student needs and placing the nonmajors class in the human sciences building. Within minutes, the department heads began collaborating to brainstorm ways to move the classroom and create a separate section, and they declared they could make it happen by the next fall semester. Finally, they proposed that we also collaborate on some future research about the changes. Altogether, in just thirty minutes, major pedagogical and curricular changes began to take form after years of frustration on the part of students and instructors alike. Those department chairs report that they continue to work together toward those suggested changes: new classrooms have been reserved for the fall in the human sciences building 
for the nonmajors section, and other faculty are excited about the developments.

An important lesson for faculty developers extending from this experience is that while these department heads clearly knew that change was needed, they required an objective outsider to motivate and facilitate that change by providing solid evidence and a rationale for change. As Cook (2001) points out, one benefit of faculty developer involvement in curricular revision is the objectivity and empirical data we can provide. As that objective observer, I also helped provide a greater sense of urgency, as Gardiner (2005) called for, and made sure to offer suggestions that were not only based on evidence but also were within the comfort zones of faculty in charge, making change easier to embrace (Hodges, 2006). Furthermore, although my objectivity and respectfulness played an important role in department head openness and the success of the meeting, they also expected me to offer suggestions since I called the meeting. Therefore, preparation is paramount for faculty developers who are aiming to take this proactive approach. This experience demonstrates that with the right combination of initiative, evidence, and consideration, higher-level change is in fact possible.

\section{Change for the Future}

The final level of change lies in the big picture for instructors who feel they do not have the authority to change their current classroom situation. Just as we did with Louise, Alex, and Ashley, and even when department- or program-level change is impossible, faculty developers can always help instructors think about the big picture of their teaching, beyond the current course that is out of their control and toward the future that will be in their control. A critical element in reaching toward that future change comes from the power of reflection (Boye \& Meixner, 2010; Brookfield, 1995; Loughran, 2002; McAlpine \& Weston, 2000). Reflection is a core value of the TEACH Program, and we encourage our participants to make it a career-long habit. Reflective practice has proven to be an especially powerful tool for instructors who feel disenfranchised from the courses they teach because it offers them an outlet for realizing that they can have a personal teaching philosophy and that their pedagogy can be different; thus, they can look forward to the time when they will be able to implement their own teaching philosophy on their terms.

Faculty developers at our center assisted Louise, Alex, and Ashley with several activities to help them engage in such big-picture reflection, first and foremost being the creation of teaching philosophy statements and 
teaching portfolios. The very process of thinking about their beliefs about teaching and how they would choose to act on those beliefs in the classroom, along with the support of faculty developers to help cultivate that reflection, provides instructors with an evocative outlet for selfrealization. In other words, it helps give them a voice when perhaps they feel voiceless, and that is a compelling experience for anyone. Other valuable reflective activities for the instructors in the study included the hypothetical course redesign that Ashley completed-her answer to "how I would teach this course if I had complete control"-and Alex's focus on creating a list of strategies for teaching large enrollment courses.

Interviews with course instructors confirm the benefit of these efforts toward recognizing big-picture change and future control. One instructor commented that "her involvement with the TEACH Program and faculty developers profoundly assisted her in developing her own philosophy of teaching and determining what was most important to her." Another mentioned a more tangible benefit of these activities, crediting "the development of her teaching philosophy and portfolio with securing her current faculty position at another university." The GSIs in this study have since moved on from teaching the food sanitation course and can now happily put into practice their own personal philosophies of teaching.

\section{Conclusion}

Louise, Alex, and Ashley are certainly not the only instructors who might feel that they are in a no-win situation, teaching a class they feel they have no power to change. Although this case study focuses on experiences of GSIs, it represents the experience of instructors populating every campus, including new faculty, lecturers, and adjuncts. Involvement with these instructors and their supervisors reveals that regardless of appearances, faculty developers can effect change in a variety of practical ways. Faculty developers can bring a wealth of attributes to instructors in need, from the neutrality and confidentiality we offer in our consultation practices, to the empirical evidence we can provide. Through preparedness and thoughtful effort, we can help even those instructors in limitedcontrol situations with small, immediate issues that still have significant impact on their personal satisfaction and professional growth. Moreover, we can become proactive agents for change on a larger scale, with the appropriate amount of convincing data and objectivity. And more than that, we can help frustrated instructors think about their teaching and discover their personal teaching philosophies so that when the time comes, they will be ready to implement them. One day these instructors 
likely will have control over their curriculum and pedagogy. By then, they will be well-prepared, reflective practitioners who are ready to embrace and influence whatever the classroom has in store for them.

\section{REFERENCES}

Association of American Universities. (1998). Committee on Graduate Education: Report and recommendations. Washington, DC: Author. Retrieved from www.aau.edu/WorkArea/showcontent.aspx?id=6720 Boice, R. (1984). The relevance of faculty development for teachers of psychology. Teaching of Psychology, 11(1), 3-8. doi:10.1207/ s15328023top1101_1

Boye, A., \& Meixner, M. (2010). Growing a new generation: Promoting selfreflection through peer observation. In J. E. Miller \& J. E. Groccia (Eds.), To improve the academy: Vol. 29. Resources for faculty, instructional, and organizational development (pp. 18-31). San Francisco, CA: Jossey-Bass.

Brookfield, S. D. (1995). Becoming a critically reflective teacher. San Francisco, CA: Jossey-Bass.

Clark, D., \& Redmond, M. (1982). Small group instructional diagnosis: Final report. Retrieved from ERIC database. (ED217954)

Cook, C. (2001). The role of a teaching center in curricular reform. In D. Lieberman \& C. Wehlburg (Eds.), To improve the academy: Vol. 19. Resources for faculty, instructional, and organizational development (pp. 217-230). San Francisco, CA: Jossey-Bass.

Diamond, R. M. (2005). The institutional change agency: The expanding role of academic support centers. In S. Chadwick-Blossey \& D. R. Robertson (Eds.), To improve the academy: Vol. 23. Resources for faculty, instructional, and organizational development (pp. 24-36). San Francisco, CA: Jossey-Bass.

Fletcher, J. J., \& Patrick, S. K. (1998). Not just workshops anymore:

The role of faculty development in reframing academic priorities. International Journal for Academic Development, 3(1), 39-46. doi:10.1080/1360144980030106

Gaff, J. G. (2002a, November/December). Preparing future faculty and doctoral education. Change, 34(6), 63-66.

Gaff, J. G. (2002b). The disconnect between graduate education and faculty realities. Liberal Education, 88(3), 6-13.

Gardiner, L. F. (2005). Transforming the environment for learning: A crisis of quality. In S. Chadwick-Blossey \& D. R. Robertson (Eds.), To improve the academy: Vol. 23. Resources for faculty, instructional, and organizational development (pp. 3-23). San Francisco, CA: Jossey-Bass. 
Golde, C. M., \& Dore, T. M. (2001). At cross purposes: What the experiences of today's graduate students reveal about doctoral education. Philadelphia, PA: Pew Charitable Trusts. Retrieved from www.phd-survey .org/report\%20final.pdf

Hativa, N. (2000). Becoming a better teacher: A case of changing the pedagogical knowledge and beliefs of law professors. Instructional Science, 28(5/6), 491-523.

Hodges, L. (2006). Preparing faculty for pedagogical change: Helping faculty deal with fear. In S. Chadwick-Blossey \& D. R. Robertson (Eds.), To improve the academy: Vol. 24. Resources for faculty, instructional, and organizational development (pp. 121-134). San Francisco, CA: Jossey-Bass.

Kuther, T. L. (2003). Teaching the teacher: Ethical issues in graduate student teaching. College Student Journal, 37(2), 219-223.

Loughran, J. J. (2002). Effective reflective practice: In search of meaning in learning about teaching. Journal of Teacher Education, 53(1), 33-43. doi: $10.1177 / 0022487102053001004$

Marshall, E. (2003). Victims of circumstance: Academic freedom in a contingent academy. Academe, 89(3), 45-48.

McAlpine, L., \& Weston, C. (2000). Reflection: Issues related to improving professors' teaching and students' learning. Instructional Science, 28(5/6), 363-385.

Meacham, J. (2002). Our doctoral programs are failing our undergraduate students. Liberal Education, 88(3), 22-27.

Park, C. (2002). Neither fish nor fowl? The perceived benefits and problems of using graduate teaching assistants (GTAs) to teach undergraduate students. Higher Education Review, 35(1), 50-62.

Prieto, L. R., \& Meyers, S. A. (1999). Effects of training and supervision on the self-efficacy of psychology graduate teaching assistants. Teaching of Psychology, 26(4), 264-266.

Schneider, A. (1999, December 10). To many adjunct professors, academic freedom is a myth. Chronicle of Higher Education, pp. A18-A19.

Thompson, K. (2003). Contingent faculty and student learning: Welcome to the strativersity. In E. Benjamin (Ed.), New directions for higher education: No. 123. Exploring the role of contingent instructional staff in undergraduate learning (pp. 41-47). San Francisco, CA: Jossey-Bass.

Turner, J. L., \& Boice, R. (1986). Coping with resistance to faculty development. In M. Svinicki, J. Kurfiss, \& J. Stone (Eds.), To improve the academy: Vol. 5. Resources for faculty, instructional, and organizational development (pp. 26-36). Stillwater, OK: New Forums Press. 
Weisbuch, R. (2004). Toward a responsive Ph.D.: New partnerships, paradigms, practices, and people. In D. H. Wulff \& A. E. Austin (Eds.), Paths to the professoriate: Strategies for enriching the preparation of future faculty (pp. 217-235). San Francisco, CA: Jossey-Bass.

Zahorski, K. (1993). Taking the lead: Faculty development as institutional change agent. In D. L. Wright \& J. P. Lunde (Eds.), To improve the academy: Vol. 12. Resources for faculty, instructional, and organizational development (pp. 227-245). Stillwater, OK: New Forums Press. 